Frontiers: The Interdisciplinary Journal of Study Abroad

(c) 2021 Iris Berdrow et al.

The work is licensed under the Creative Commons Attribution-NonCommercial-NoDerivatives

4.0 International License.

Volume 33, Issue 1, pp. 43-62

DOI 10.36366/frontiers.v33i1.514

FORUM

ON EDUCATION

ABROAD

\title{
The Bentley Global Experience
}

Initiative: An Application of

Assessment Data towards

\section{Pedagogical Development}

Iris Berdrow ${ }^{1}$, Samir Dayal ${ }^{1}$, Shawn Hauserman ${ }^{1}$, Natalie Schlegel ${ }^{1}$, Lauren Schuller ${ }^{1}$

\begin{abstract}
Since 2009, Bentley University has engaged in assessment of intercultural effectiveness in undergraduate students. The instrument used was the Intercultural Effectiveness Scale, which measures six dimensions using a self-report instrument. The longitudinal data analysis showing results in correlation and causation indicated that while international education experiences have a significant positive effective on Global Mindset, they do not indicate a positive significant effect on other dimensions of intercultural effectiveness (Berdrow, Woolford, Skaletsky, Bird; 2020). In 2018, Bentley University engaged in a curriculum design process to re-envision its undergraduate core curriculum. Taking the opportunity to apply lessons from the assessment of intercultural effectiveness, a component of the new design was the Global Experience. This paper briefly outlines the assessment initiative and the curriculum design outline, with an emphasis on the creation of the Bentley Global Experience Initiative, a comprehensive program supporting faculty and students.
\end{abstract}

\section{Keywords:}

global education, assessment, intercultural competence, higher education, student learning outcomes

\section{Assessment of Intercultural Effectiveness at Bentley University}

Bentley University is a private university that was founded in 1917. Located in Waltham, Massachusetts, its setting is suburban, and the campus size is 163 acres. The

1 BENTLEY UNIVERSITY, WALTHAM, MA, USA

Corresponding Author: Iris Berdrow, iberdrow@bentley.edu 
university is focused on business, with undergraduate, master's degree and PhD programs. It has a total undergraduate enrollment of 4,253 , and graduate enrollment of 1,200 . The unique organizational structure of Bentley is that the business and arts \& sciences faculty have joint representation on all major curricular decisions through a single faculty senate. While their respective Dean represents the departments, whether business or arts \& sciences, all departments are jointly represented by the Provost and Faculty Senate. In addition, the undergraduate curriculum consists of general education (GenEd) requirements, general business (GB) requirements, and majors/minors. Students take both GenEd and GB courses throughout their four years. In this way, Bentley is a university within a business school, graduating approximately $98 \%$ of its students with a BS in a business major. There are also options for a BA major ( $2 \%$ of graduates), a dual Liberal Studies major, and a BA minor. Approximately $50 \%$ of undergraduates take a study abroad, whether short-term faculty led, summer, semester, or academic year.

Bentley is an ideal institution in which to consider the curriculum design process, particularly one based on assessment of learning data. The institution has a deep commitment to assessment processes. It was one of the first institutions to voluntarily be reviewed against the new AACSB accreditation standards in the late 1990's, the first to include assessment of learning outcomes. It has committed to longitudinal assessment of learning outcomes across business and liberal arts programs. The curriculum design process was a longitudinal, multi-phase initiative specifically based on backward design looking at the desired outcomes before choosing the curricular content. The results of the longitudinal assessment of intercultural effectiveness informed the design of the Global Experience. Hence, Bentley provides a full circle example of assessment leading to curriculum design. Following this process, we next describe the assessment project and then the curriculum design process.

Beginning in 2009, Bentley has engaged in the Intercultural Effectiveness Assessment project to understand the intercultural effectiveness of undergraduate students, and the impact of international education experiences on those competencies. Multiple objectives were served by this study including:

- facilitating student awareness and development of their intercultural effectiveness.

- $\quad$ providing faculty with materials to incorporate intercultural effectiveness into their course delivery.

- $\quad$ assessing Intercultural Effectiveness as a learning outcome.

- informing curricular development discussions, particularly in the strategic domain of globalizing the curriculum; and

- developing an instrument to effectively measure the factors impacting student intercultural effectiveness.

The assessment model has been described in Berdrow and Bird; 2018. The model is based on Astin's Input-Environment-Output (I-E-O) model of assessment. Astin (1985) suggested that to truly understand a learning outcome (in this case, intercultural effectiveness), one must consider the inputs and the environment relevant to that outcome.

Inputs provide information to understand what the student brings to the learning experience. Inputs include fixed variables such as gender, high school Grade Point Average, 
family Socio Economic Status, SAT (student achievement test) scores, and changeable variables such as intended major, attitudes, beliefs, goals, motivation, cognitive skills.

Elements of the environment provide information to understand what value the international education experience adds to student learning. These elements fall into four categories: (1) Places - impact of the physical environments on learning effectiveness. (2) Programs - impact of academic and non-academic experiences on learning effectiveness. (3) Processes - impact of academic and administrative systems of selecting, processing, educating, assessing students on learning effectiveness. (4) People - who are the people that shape the learning effectiveness of students.

The outcome is the desired learning objective, in this case intercultural effectiveness. Specifically, the instrument used to measure intercultural effectiveness was the Intercultural Effectiveness Scale developed by Kozai Group. Currently there are 10 commonly used intercultural competence assessment tools available to measure the development of intercultural and global leadership competencies. For a complete overview of assessments, see Bird, Oddou, \& Bond (Forthcoming). For this study, several factors were considered in selecting an appropriate instrument. These include the validity and reliability of the instrument, how closely the instrument measures competencies related to intercultural effectiveness, if the instrument requires formal training to administer and interpret results, how long a single assessment takes to complete, and the cost per respondent.

The IES competencies are based on three broad facets or dimensions for individuals (Bhaskar-Shrinivas, et. al., 2005; Mendenhall \& Oddou, 1985; Black et. al., 1991; Thomas, 1998: 247). Continuous Learning addresses the cognitive/perceptual domain. Interpersonal Engagement addresses the other/relationship domain. Hardiness addresses the self/self-efficacy domain. These align with our desired affective, behavioral, and cognitive dimensions. The IES measures six dimensions categorized into these three factors of IE: Self-Awareness and Exploration (Continuous Learning); Global Mindset and Relationship Interest (Interpersonal Engagement); and Open-Mindedness and Emotional Resilience (Hardiness). Definitions for each are provided in Table I along with the item reliability scores (Mendenhall, Stevens, Bird, \& Oddou, 2008). The six dimensions were used in this study as the measures of the intercultural effectiveness outcomes.

This instrument was chosen because it measured variables directly correlated with Bentley's learning objectives, it is user friendly offering online accessibility, and it offers results to two stakeholders - the respondents in the form of a 24-page explanatory report and the administrators in the form of the raw data results. This lends itself to use as both a learner-centered development tool as well as a program-level assessment instrument.

The outcomes of this initiative have been multifaceted, including pedagogical design (Berdrow, Hightower \& Cartwright, 2020) and data analysis (Berdrow, Woolford, Skaletsky and Bird, 2020). In summary, the data analysis showed that while four dimensions of intercultural effectiveness did increase with time, for most aspects of intercultural effectiveness the pre-to-post increase was not correlated with an intervening international education experience. The exception was global mindset. See Table 2 for a summary of the results along with definitions of the dimensions. 


\begin{tabular}{|c|c|c|}
\hline \multicolumn{2}{|c|}{$\begin{array}{c}\text { Table 1: Intercultural Effectiveness Survey (IES) } \\
\text { Dimensions }{ }^{1}\end{array}$} & \multirow[t]{2}{*}{$\begin{array}{l}\text { Reliability } \\
\text { Score }\end{array}$} \\
\hline Core Dimensions & Sub Dimensions (Dependent Variables) & \\
\hline \multirow{2}{*}{$\begin{array}{l}\text { Continuous } \\
\text { Learning } \\
\text { Degree to which you } \\
\text { engage the world by } \\
\text { continually seeking to } \\
\text { understand and learn } \\
\text { about the activities, } \\
\text { behavior, and events } \\
\text { that occur around } \\
\text { you }\end{array}$} & $\begin{array}{l}\text { SELF-AWARENESS } \\
\text { Degree to which you are aware of your personal } \\
\text { values, strengths, weaknesses, interpersonal style, } \\
\text { and behavioral tendencies, the impact of these } \\
\text { things on other people; and the degree to which } \\
\text { you reflect on this knowledge about yourself in } \\
\text { order to engage in personal development and } \\
\text { learning activities. }\end{array}$ & 0.76 \\
\hline & $\begin{array}{l}\text { EXPLORATION } \\
\text { Extent to which you are open to and pursue an } \\
\text { understanding of ideas, values, norms, situations, } \\
\text { and behaviors that are different from your own; } \\
\text { and the ability to learn from mistakes and to make } \\
\text { adjustments to your personal strategies to ensure } \\
\text { success in what you do. }\end{array}$ & 0.82 \\
\hline \multirow{2}{*}{$\begin{array}{l}\text { Interpersonal } \\
\text { Engagement. } \\
\text { Interest in other } \\
\text { cultures and the } \\
\text { importance of } \\
\text { developing } \\
\text { relationships with } \\
\text { people from other } \\
\text { cultures, generally } \\
\text { speaking. }\end{array}$} & $\begin{array}{l}\text { GLOBAL MINDSET } \\
\text { Degree to which you are interested in, and seek to } \\
\text { actively learn about, other cultures and the people } \\
\text { that live in them. }\end{array}$ & 0.84 \\
\hline & $\begin{array}{l}\text { RELATIONSHIP INTEREST } \\
\text { Extent to which you are likely to initiate and } \\
\text { maintain positive relationships with people from } \\
\text { other cultures; and whether engaging others is an } \\
\text { energy-producing or energy-depleting activity for } \\
\text { you. }\end{array}$ & 0.80 \\
\hline \multirow{2}{*}{$\begin{array}{l}\text { Hardiness } \\
\text { Ability to effectively } \\
\text { manage your } \\
\text { thoughts and } \\
\text { emotions in } \\
\text { intercultural } \\
\text { situations, along with } \\
\text { your ability to be } \\
\text { open-minded and } \\
\text { nonjudgmental about } \\
\text { ideas and behaviors } \\
\text { that are new to you. }\end{array}$} & $\begin{array}{l}\text { OPEN-MINDEDNESS } \\
\text { Degree to which you withhold judgments about } \\
\text { situations and people that are new or unfamiliar to } \\
\text { you; and to which you are open to alternative } \\
\text { perspectives and behaviors, in general. }\end{array}$ & 0.79 \\
\hline & $\begin{array}{l}\text { EMOTIONAL RESILIENCE } \\
\text { Level of emotional strength and your ability to cope } \\
\text { with challenging emotional experiences; your } \\
\text { capacity to recover quickly from psychologically } \\
\text { and emotionally stressful or challenging situations. }\end{array}$ & 0.81 \\
\hline
\end{tabular}

Based on the collective experience of faculty, international education professionals, and literature it is our belief that the lack of significant correlation between most aspects of intercultural effectiveness and international education experiences can be attributed to a number of things, including inconsistent design of study abroad international education experiences (Paige, 1993), inconsistent commitment of faculty to including intercultural effectiveness as a learning objective for faculty-led international education experiences (Leeman and Ledoux, 2005), and inconsistent requirements of students engaged in international education experiences (Gaudelli and Laverty, 2015). While it would be easy

\footnotetext{
1 @The Kozai Group, Inc. 2007. This is a proprietary instrument so individual items cannot be published here.
} For the full IES technical report see, https://www.kozaigroup.com/intercultural-skills/. 
to put the responsibility for outcomes squarely on the students, the Academy of International Business Insights Journal Special Issue on Responsibilities of Educators in International Business remind us that institutions and faculty (Hruby, Calixto and Mukhi, 2020) play a crucial role, and the use of appropriate tools such as high-impact practices ${ }^{2}$ (Schmidt-King, 2020) and assignments (Berg, 2020) are relevant to the learning outcomes we seek.

\section{Table 2. Summary Results of Assessment Data Analysis}

\begin{tabular}{|c|c|c|}
\hline $\begin{array}{l}\text { Dependent Variables } \\
\text { (Post-Pre) } \\
\text { IE Dimension }\end{array}$ & $\begin{array}{c}\text { Model } 1 \text { Results } \\
\text { Correlation Relationship between } \\
\text { pre and post measures }\end{array}$ & $\begin{array}{c}\text { Model } 2 \text { Results } \\
\text { Causal Relationship } \\
\text { between pre/post change } \\
\text { and an intervening int'l } \\
\text { educ'n experience }\end{array}$ \\
\hline $\begin{array}{l}\text { Self-Awareness: Degree } \\
\text { to which you are aware } \\
\text { of your personal values, } \\
\text { strengths, weaknesses, } \\
\text { interpersonal style, and } \\
\text { behavioral tendencies, } \\
\text { the impact of these } \\
\text { things on other people; } \\
\text { and the degree to which } \\
\text { you reflect on this } \\
\text { knowledge about } \\
\text { yourself in order to } \\
\text { engage in personal } \\
\text { development and } \\
\text { learning activities. }\end{array}$ & Positive and significant & $\begin{array}{l}\text { Not significantly different } \\
\text { from } 0\end{array}$ \\
\hline $\begin{array}{l}\text { Exploration: Extent to } \\
\text { which you are open to } \\
\text { and pursue an } \\
\text { understanding of ideas, } \\
\text { values, norms, } \\
\text { situations, and } \\
\text { behaviors that are } \\
\text { different from your own; } \\
\text { and the ability to learn } \\
\text { from mistakes and to } \\
\text { make adjustments to } \\
\text { your personal strategies } \\
\text { to ensure success in } \\
\text { what you do. }\end{array}$ & Positive and significant & $\begin{array}{l}\text { Not significantly different } \\
\text { from } 0\end{array}$ \\
\hline $\begin{array}{l}\text { Global Mindset: Degree } \\
\text { to which you are } \\
\text { interested in, and seek } \\
\text { to actively learn about, } \\
\text { other cultures and the } \\
\text { people that live in them. }\end{array}$ & Positive and significant & Positive and significant \\
\hline
\end{tabular}

\footnotetext{
2 The Association for American Colleges \& Universities (AAC\&U) describes the following as high-impact practices: first-year seminars and experiences; common intellectual experiences; learning communities; writing-intensive courses; collaborative assignments and projects; undergraduate research; diversity/global learning; e-portfolios; service-learning, community-based learning; internships; and capstone courses and projects.
} 


\begin{tabular}{|c|c|c|}
\hline $\begin{array}{l}\text { Relationship Interest: } \\
\text { Extent to which you are } \\
\text { likely to initiate and } \\
\text { maintain positive } \\
\text { relationships with } \\
\text { people from other } \\
\text { cultures; and whether } \\
\text { engaging others is an } \\
\text { energy-producing or } \\
\text { energy-depleting activity } \\
\text { for you. }\end{array}$ & Not significantly different from 0 & NA \\
\hline $\begin{array}{l}\text { Open-Mindedness: } \\
\text { Degree to which you } \\
\text { withhold judgments } \\
\text { about situations and } \\
\text { people that are new or } \\
\text { unfamiliar to you; and to } \\
\text { which you are open to } \\
\text { alternative perspectives } \\
\text { and behaviors, in } \\
\text { general. }\end{array}$ & Not significantly different from 0 & NA \\
\hline $\begin{array}{l}\text { Emotional Resilience: } \\
\text { Level of emotional } \\
\text { strength and your ability } \\
\text { to cope with challenging } \\
\text { emotional experiences; } \\
\text { your capacity to recover } \\
\text { quickly from } \\
\text { psychologically and } \\
\text { emotionally stressful or } \\
\text { challenging situations. }\end{array}$ & Positive and significant & $\begin{array}{l}\text { Not significantly different } \\
\text { from } 0\end{array}$ \\
\hline
\end{tabular}

One concern about the current structure at Bentley was the separation between the International Education administrative department, the Global Studies academic department, and business departments such as Management. International Education approves faculty-led programs according to a template but has no power to enforce compliance with design components. They also manage study abroad, which transfers the responsibility for education and evaluation of learning outcomes to partner institutions. Global Studies offers the prerequisite courses for study abroad but there lacks collaboration that might ensure a common preparation, and alignment of learning objectives with the study abroad program. Management (as an example) offers faculty-led programs but the design ranges from focusing on specific functional areas with an emphasis on cultural competence development, to a general "learning about business in <insert country>”.

\section{Undergraduate Curriculum Reform Initiative}

In 2018, Bentley University engaged in a multi-year, multi-phase undergraduate curriculum reform process. In Fall 2018, the Faculty Senate initiated an Undergraduate Curriculum Revision Process. The initiative was to take several stages following a backward design approach. It began with faculty approval of five learning goals written by Bentley's Phase One Task Force. Phase Two Task Force created Student Learning Outcomes for each of the Learning Goals passed in Phase One. In May 2019, Phase Three Task Force (TF3.0) was charged with designing a new structure for an integrated Bentley Core Curriculum 
through which students will realize the Learning Goals and Student Learning Outcomes create in Phases One and Two respectively. The proposed structure was to outline a core curriculum that meets three overarching goals:

1. Integrative, providing a more coherent and connected student experience with meaningful learning across all four years.

Curriculum integration has long been proposed as a way of organizing the "common learnings" or life skills considered essential for all citizens in a democracy (Drake, 1993). Curriculum is organized around real-life problems and issues significant to both young people and adults, applying pertinent content and skills from many subject areas or disciplines. The intent is to help students make sense out of their life experiences and learn how to participate in a democracy (Beane, 1997).

The Integrated Curriculum Model (ICM), first proposed in 1986, is comprised of three interrelated dimensions (adapted):

1. Emphasizing advanced content knowledge that frames disciplines of study.

2. Providing higher-order thinking and processing.

3. Organizing learning experiences around major issues, themes, and ideas that define understanding of a discipline and provide connections across disciplines.

The question to be asked is, what is being integrated and at what level? A review of integrated curriculum models showed that while many integrated within disciplines, none integrated across disciplines, nor integrated discipline specific requirements with general education requirements (Vars and Beane, 2000)). Since Bentley is business university, the opportunity for integrating across business and liberal arts is part of Bentley's culture. Yet, in practice, many structural impediments prevent true integration.

An equally important question is whether an integrative curriculum is effective. It is still too early to obtain reliable data on how students in integrative programs fare on state proficiency tests. However, recent analyses of studies (National Association for Core Curriculum, 2000; Vars, 1996, 1997; Arhar, 1997) point to the same general conclusion: Almost without exception, students in any type of interdisciplinary or integrative curriculum do as well as, and often better than, students in a conventional departmentalized program. These results hold whether the combined curriculum is taught by one teacher in a self-contained or block-time class or by an interdisciplinary team (Vars, 2000). Yet another reason for Bentley to take the opportunity to develop a truly integrative approach has to do with domestic as well as global perspectives, problems, and solutions. A truly integrative approach would be flexible and experiential.

2. Flexible, offering students different learning pathways and accommodating transfer students more easily. An integrated curriculum allows for crossdisciplinary learning objectives such as cultural competencies to be developed throughout appropriate courses, regardless of whether they are in Global Studies, Modern Languages, Management, or other disciplines. This is in keeping with the longitudinal multifaceted process required for development of global competencies.

3. Experiential, delivering opportunities for students to achieve core student learning outcomes through traditional courses as well as co-curricular or extracurricular experiences. In Dancing at the Edge, authors O'Hara and Leicester 
(2012) argue that our increasingly complex, chaotic world calls for a new perspective on competence and competence development. To date, the response has been to add more and more requisite competencies to the list resulting in a neurotic response.

Another more recent report - Thriving in the $21^{\text {st }}$ Century - is even more comprehensive, listing 81 relevant "competencies, qualities and attributes" ranging from 'scanning and interpreting the environment' to 'finding others to work with who complement your strengths'. Though certainly not wrong - these competencies are undoubtedly useful and if mastered would enhance a persons' ability to perform successfully in $21^{\text {st }}$-century work settings - the lists themselves betray a fundamentally neurotic response to today's cultural crisis. They are almost compulsive attempts to deny that things are unmanageable, offering instead the comforting promise that all can be mastered if only one has these skills. (p.866)

O'Hara and Leicester further agree with a five-year, multinational research study by the OECD that "Competence is the ability to meet important challenges in life in a complex world." (p.999, 1009). "The capacity is a quality of the individual, the competence is expressed in action - and can be developed to the point of mastery" (p.1027).

The enabling condition is the learning context: "The ability to meet important challenges in a complex world is learned through the experience of engaging with complex challenges that are motivating and significant for the participants involved.” (p.1125)

\section{The Global Experience Component of the Curriculum Design}

The undergraduate curriculum structure put forth by TF3.0 includes a "global experience" for all undergraduate students to be completed during their junior year. The global experience is a three credit, immersive, facilitated exploration of culture. Global Experiences help students understand culture (both their own and that of others), manage themselves and their relations with others in the context of cultural complexity, and take ownership for lifelong intercultural development. Global Experience proposals could include a study abroad experience but could also involve immersive explorations with significant experiences outside the classroom that enable students to gain global insight. Given the strategic mission of Bentley, at a minimum, all Global Experiences should address the following learning outcomes: cultural perspectives, global learning, intercultural effectiveness, and lifelong learning.

The purpose of the Global Experience is to:

- Understand culture, one's own and that of others

- Manage oneself and relations with others effectively in the context of cultural complexity

- Respect cultures and refrain from judgment

- Learn from cultures and apply that learning to new contexts

- Take responsibility for one's own lifelong intercultural development

The business world, and the societies in which it operates, is increasingly interconnected on a global scale. Each individual, group, organization and society is conditioned and socialized in its values, attitudes, beliefs, and norms of behavior. Conditioning and socialization come from the ground up through everyday practices of individuals and groups, and through regulatory systems governing nations. These cultural 
practices and institutions drive our way of being and working. The only way to understand our own and those of others is through transformational experience within a structure of concepts, benchmarks, reflection, and practice.

This Key Learning Experience is a structure supporting a variety of immersive, facilitated Global Experiences by which students can fulfill their cultural perspectives, global learning, intercultural effectiveness, and lifelong learning outcomes. The Global Experience structure includes three student requirements:

1. A Culture in Business \& Society Workshop

2. One of 5 suggested Global Experience Options (more may be identified in the future)

3. An End of Program Reflection Module

The Global Experience structure also includes the following supporting elements:

1. Global Experience Coaches for students on Study Abroad

2. Global Experience Workshop for faculty running Faculty Led Programs and Modern Languages Experiences

3. Program Coordinator for International Service Learning Experiences

4. End of Program Reflection coordinator

Students complete the three requirements to achieve the learning outcomes plus three credits. See Figure 1 for the Global Experience Design

\section{Culture in Business \& Society Workshop}

Two mandatory half-Saturday workshops are the gateway into a student's Global Experience and must be completed prior to enrollment in a Global Experience. They are offered twice a semester. Workshops are designed and delivered initially by Management and Global Studies faculty trained in cross-cultural pedagogy. Other faculty and staff will be added to increase engagement and ownership in the program. The objective is to prepare every interested student, faculty, and staff member for a cultural immersion experience, to standardize Bentley's understanding of cultural diversity, and to create a student-centered approach to the development of intercultural effectiveness.

Topics include:

- Understanding culture

- Identifying relevant cultural frames

- Communicating within and across cultures

- $\quad$ Functioning effectively within cultural multiplicity

- Intercultural effectiveness assessment using the IES

- $\quad$ Critical critique of one's own culture and cultural blindness

- $\quad$ Creating a personal development plan 


\section{Figure 1.Global Experience Design}

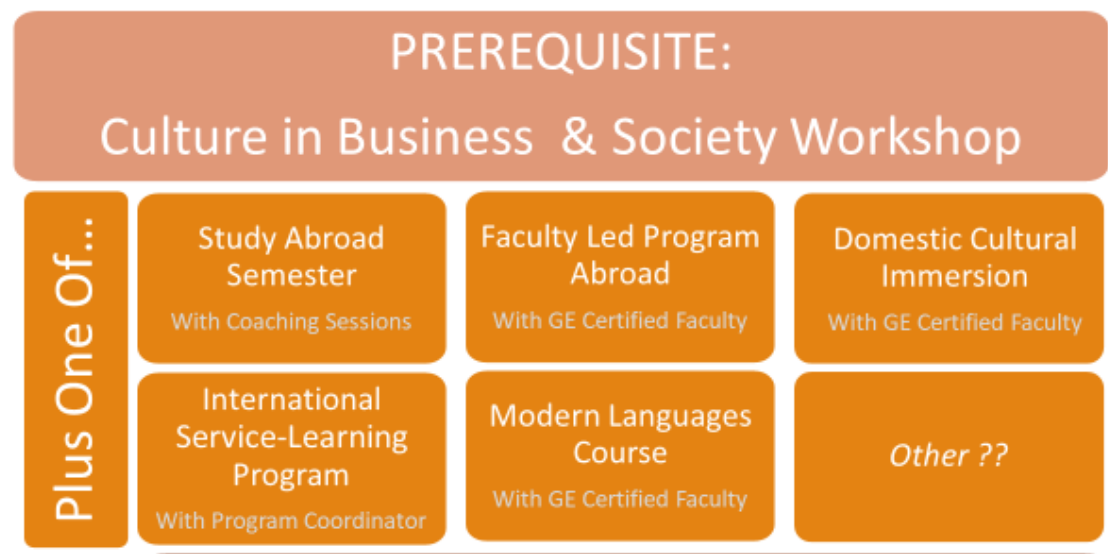

\section{Plus End of Program Reflection Module}

The 3 Credit Global Experience

\section{Global Experience Options}

Each student can choose one or more of the following Global Experience options. Each option is designed to include mentorship, reflection and immersion within a non-US cultural group or location. The intent for Global Experiences is to strive towards transformational learning. Transformative learning may be defined as learning that transforms problematic frames of reference to make them more inclusive, discriminating, reflective, open, and emotionally able to change. (Mezirow, Taylor \& Associates 2009). A transformative learning experience requires that the learner make an informed and reflective decision to act or not. This decision may result in immediate action or delayed action, caused by situational constraints, or lack of information on how to act, or a reasoned reaffirmation of an existing pattern of action.

Vande Berg's model of Phases of Learning suggests that cultural learners move through the following stages of learning evolution (Vande Berg M., 2016):

- $\quad$ Phase I: Exposure - the assumption made is that experience equals learning.

- Phase II: Relativism - a consideration of what is common and what is different (that matters) between my culture and theirs.

- $\quad$ Phase III: Constructivism - by reflecting on the experience the sojourner begins to make sense of their learning.

- Phase IV: Transformation - I can begin to shift my frame of reference and adapt my behaviors to the cultural context in which I find myself.

Global Experiences are designed for Phase III and Phase IV outcomes. The guidelines for achieving transformation learning are that the GE must include a cultural context; guided reflections on the impact of that cultural context on values, attitudes, beliefs, and norms of behavior; and student assessment of their own personal development. The student must be active and intentional in their own cultural learning, while also being guided and supported through the challenges of that journey. 
Study Abroad (SA): One year, one semester or summer enrollment at a Bentley Partner Institution. Before departing, students will be assigned a global experience coach. The coach will review the personal development plan and check in with students during their study abroad. The check-in sessions are conducted via Zoom and can include students from multiple study abroad locations. The check-in sessions are guided by reflection prompts such as:

1. What was my most powerful experience to date?

2. What did I learn from it? And how?

3. Which of the challenges in my development plan did I achieve?

4. What tools do I reach for when feeling vulnerable, confused, disoriented?

5. What questions do I have?

Faculty Led Program (FLP) Abroad: An embedded or short-term program delivered in the context of a topical course. Faculty leading these programs will have completed a cultural context workshop designed to ensure all programs offer immersive transformational learning experience, regardless of the topic or field of study. FLP's are thoughtfully designed student international opportunities that encourage reflective and comparative exercises as part of the program design and curriculum.

Domestic Cultural Immersion Experience (DCIE): For students unable to travel abroad these opportunities offer transformative immersion into unfamiliar cultures within the US. A DCIE would be proposed by interested faculty, be framed within the context of theme-based courses (for example, Can Business resolve inter-city racial tensions?), and offer students immersive experiences in an unfamiliar yet local cultural group.

International Service-Learning Program (ISL): These programs are offered through the Bentley Service-Learning and Civic Engagement Center and will be a carefully crafted set of academically based travel experiences designed to help students become culturally competent and engaged global citizens and provide meaningful contributions to local communities/nonprofit organizations. Students and faculty are required to attend pre- and post-trip trainings, activities, and meetings conducted by the Cronin Center and BSLCE. Careful partnership and project development will be identified and managed primarily by the BSLCE.

Modern Languages Immersion Course (MLIC): Students can complete a Modern Languages course provided the course includes a cultural immersion component. The immersion can be domestic and local but must involve participation with a host community interacting in the language of study. The faculty teaching these courses will have completed a cultural context workshop.

\section{End of Program Reflection Module:}

An important aspect of the global experience is to continue the assessment of both students and the program. The objective of the global experience is to enhance student outcomes but also the efficacy of global experiences. The only way to know is to track the results. The End of Program Reflection Module offers both objectives to be tracked. Both qualitative and quantitate self-assessment data are gathered from students. 
Administered by the Office of International Education, students engaged in a oneyear, single semester, or summer study abroad experience are required to complete an online reflection module. The module includes:

1. Overview of the purpose and structure of reflections.

2. Self-reflections on the learning experience based on journal entries and guided by prompting questions.

3. Post-trip self-assessments using the IES, with self-reflective analysis of changes.

4. Revised personal development plan for the future based on the changes in IES scores.

5. Overall evaluation of the global experience against initial personal objectives.

\section{Support Structures:}

Global Experiences require the following additional support structures.

Global experience coach for students on SA and international internships provided through Office of International Education. Coaches will be assigned 10-15 SA students. Students will give their coaches their Personal Development Plan from the Culture in Business \& Society Workshop. Coaches will schedule mandatory monthly check-in sessions with their group of SA students. These sessions are conducted via zoom and bring together all assigned students regardless of their SA location.

Cultural context two-half Saturday workshop for faculty running FLP's and Modern Languages Courses co-delivered twice per semester by Management and Global Studies faculty. The objectives of this workshop are to provide faculty with guiding principles on designing a transformational learning experience within their short-term study abroad programs, and to suggest ways in which they can assess the impact of those programs on student learning. The basic agenda for the workshop includes:

- Context of Culture: What is culture? Why focus on country culture?

- Transformational Learning: What does Education Abroad offer that domestic programs do not?

- Building Transformational Learning Experiences: What does the literature tell us? What are the basic building blocks?

- Assessing learning outcomes

- Design Overview: Logistics, Timeline, Key Success Factors.

Program Coordinator for international service-learning (ISL) students provided through Bentley Center for Service-Learning. While most ISL programs will be short-term faculty-led programs, if a student completes an ISL while on a study abroad, an ISL Program Coordinator will be assigned ISL students with whom they will conduct monthly check-in reflection sessions.

\section{Student-Centered Learning}

A key objective of the Global Experience is to enhance student learning. Any effective assessment program articulates to students what it is they are supposed to be learning and offers evidence of whether that learning was achieved. In course work this 
happens through the syllabus, class agendas, and student evaluations. In a comprehensive program such as the Global Experience, it may be more challenging for students to focus on the knowledge, skills and perspectives and instead focus on the excitement of a travel experience. The standardized structure of GE's achieved through faculty and staff training ensures that each GE, regardless of type, will include opportunities for development of the articulated learning objectives. The learning objectives are provided to students during the workshop and are reiterated by the coaches during mandatory check-in sessions. The development plan which students complete before the Global Experience, based on their first IES results, gives them guidance during the GE. As part of the development plan, students choose one or two dimensions and set intentions for working on them. Journaling during the GE brings them back to those intentions, as do the Coaching sessions.

The End of Program Reflection Module brings the learning objectives full circle. Students look back on their efforts, summarizing their progress, and affirming results through the post-trip IES survey. Students take responsibility for their own efforts and assess their own outcomes against the qualitative results from the IES. This ownership of the learning process embeds in students a practice of lifelong learning.

\section{Program Evaluation}

To fulfill the curriculum design objectives, all components had to demonstrate achievement of impact, integration across disciplines, and innovation. The delivery on each objective by the Global Experience is discussed next.

Impact: The GE fulfills the four learning objectives of cultural perspectives, global learning, intercultural effectiveness, and lifelong learning. For a summary of the definitions, rubrics and evaluations see Table 3. Students will complete an Intercultural Effectiveness self-assessment (IES) during the prerequisite workshop and again as part of the post-experience reflection module. The difference in pre-post change will be compared to previous pre-post IES data from Bentley students. The analysis provides program assessment data - over time, do students who participate in the GE achieve higher IES scores? Completing the End of Program Reflection Module demonstrates to students the benefits of the GE beyond a travel experience. It also provides them with language by which to describe what they have learned - a valuable marketing tool.

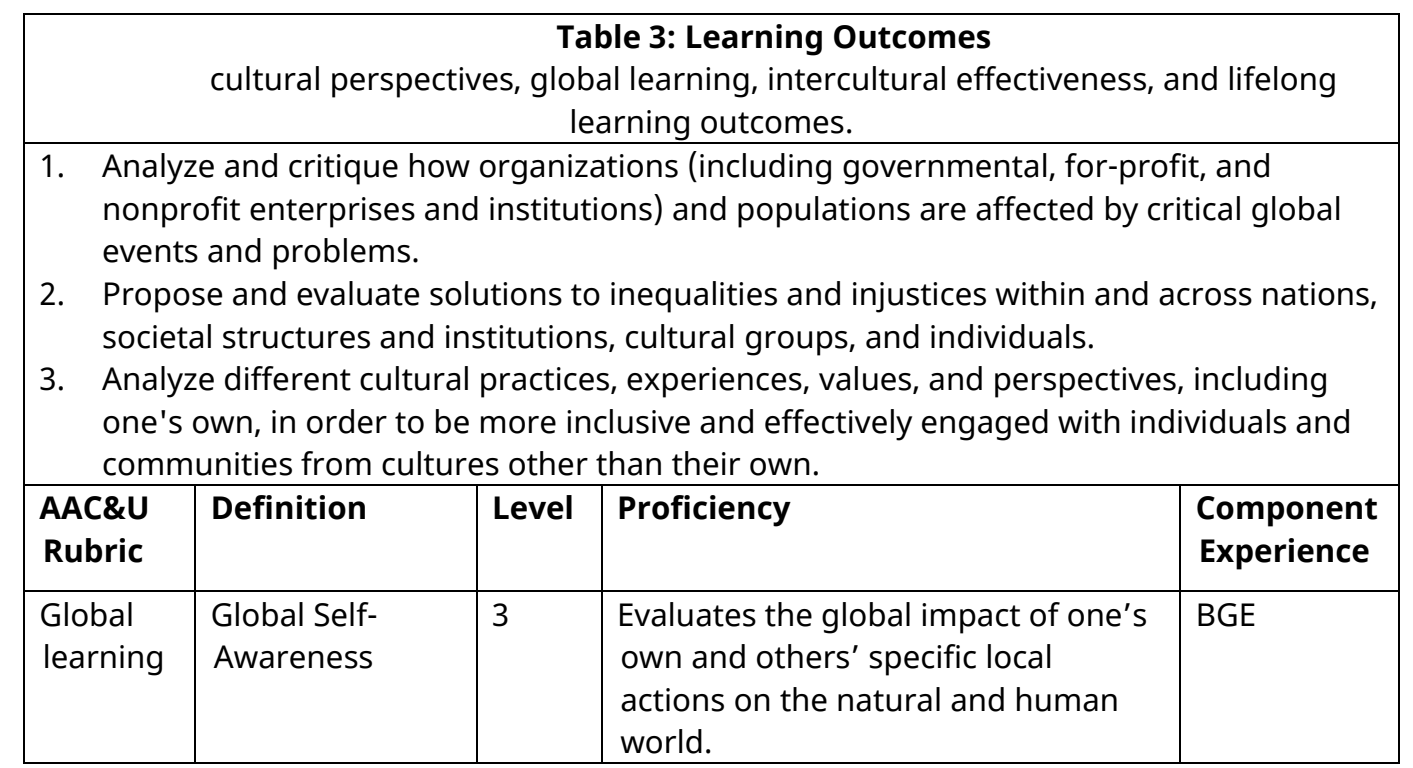




\begin{tabular}{|c|c|c|c|c|}
\hline & $\begin{array}{l}\text { Perspective } \\
\text { Taking }\end{array}$ & 3 & $\begin{array}{l}\text { Synthesizes other perspectives (such } \\
\text { as cultural, disciplinary, and ethical) } \\
\text { when investigating subjects within } \\
\text { natural and human systems. }\end{array}$ & BGE \\
\hline & $\begin{array}{l}\text { Cultural } \\
\text { Diversity }\end{array}$ & 2 & $\begin{array}{l}\text { Explains and connects two or more } \\
\text { cultures historically or in } \\
\text { contemporary contexts with some } \\
\text { acknowledgement of power } \\
\text { structures, demonstrating respectful } \\
\text { interaction with varied cultures and } \\
\text { worldviews. }\end{array}$ & BGE \\
\hline \multirow[t]{6}{*}{$\begin{array}{l}\text { Intercult } \\
\text { ural } \\
\text { Knowled } \\
\text { ge and } \\
\text { Compet } \\
\text { ence }\end{array}$} & $\begin{array}{l}\text { Knowledge: } \\
\text { cultural self- } \\
\text { awareness }\end{array}$ & 3 & $\begin{array}{l}\text { Recognizes new perspectives about } \\
\text { own cultural rules and biases (e.g., } \\
\text { not looking for sameness; } \\
\text { comfortable with the complexities } \\
\text { that new perspectives offer.) }\end{array}$ & $\begin{array}{l}\text { Prerequisite } \\
\text { Workshop }\end{array}$ \\
\hline & $\begin{array}{l}\text { Knowledge) } \\
\text { cultural } \\
\text { worldview } \\
\text { frameworks }\end{array}$ & 3 & $\begin{array}{l}\text { Demonstrates adequate } \\
\text { understanding of the complexity of } \\
\text { elements important to members of } \\
\text { another culture in relation to its } \\
\text { history, values, politics, } \\
\text { communication styles, economy, or } \\
\text { beliefs and practices. }\end{array}$ & $\begin{array}{l}\text { Prerequisite } \\
\text { Workshop } \\
\text { BGE }\end{array}$ \\
\hline & Skills: Empathy & 3 & $\begin{array}{l}\text { Recognizes intellectual and } \\
\text { emotional dimensions of more than } \\
\text { one worldview and sometimes uses } \\
\text { more than one worldview in } \\
\text { interactions. }\end{array}$ & $\begin{array}{l}\text { Prerequisite } \\
\text { Workshop } \\
\text { BGE }\end{array}$ \\
\hline & $\begin{array}{l}\text { Skills: verbal and } \\
\text { nonverbal } \\
\text { communication }\end{array}$ & 3 & $\begin{array}{l}\text { Recognizes and participates in } \\
\text { cultural differences in verbal and } \\
\text { nonverbal communication and } \\
\text { begins to negotiate a shared } \\
\text { understanding based on those } \\
\text { differences }\end{array}$ & $\begin{array}{l}\text { Prerequisite } \\
\text { Workshop } \\
\text { BGE }\end{array}$ \\
\hline & $\begin{array}{l}\text { Attitudes: } \\
\text { curiosity }\end{array}$ & 3 & $\begin{array}{l}\text { Asks deeper questions about other } \\
\text { cultures and seeks out answers to } \\
\text { these questions. }\end{array}$ & $\begin{array}{l}\text { Prerequisite } \\
\text { Workshop } \\
\text { BGE }\end{array}$ \\
\hline & $\begin{array}{l}\text { Attitudes: } \\
\text { openness }\end{array}$ & 3 & $\begin{array}{l}\text { Begins to initiate and develop } \\
\text { interactions with culturally different } \\
\text { others. Begins to suspend judgment } \\
\text { in valuing her/ his interactions with } \\
\text { culturally different others. }\end{array}$ & $\begin{array}{l}\text { Prerequisite } \\
\text { Workshop } \\
\text { BGE }\end{array}$ \\
\hline \multirow[t]{3}{*}{$\begin{array}{l}\text { Lifelong } \\
\text { Learning }\end{array}$} & Curiosity & 3 & $\begin{array}{l}\text { Explores a topic in depth, yielding } \\
\text { insight and/or information } \\
\text { indicating interest in the subject. }\end{array}$ & BGE \\
\hline & Initiative & 3 & $\begin{array}{l}\text { Completes required work, identifies } \\
\text { and pursues opportunities to } \\
\text { expand knowledge, skills, and } \\
\text { abilities. }\end{array}$ & BGE \\
\hline & Independence & 3 & $\begin{array}{l}\text { Beyond classroom requirements, } \\
\text { pursues substantial, additional } \\
\text { knowledge and/or actively pursues } \\
\text { independent educational } \\
\text { experiences. }\end{array}$ & BGE \\
\hline
\end{tabular}




\begin{tabular}{|l|l|l|l|l|}
\hline Transfer & 3 & $\begin{array}{l}\text { Makes references to previous } \\
\text { learning and shows evidence of } \\
\text { applying that knowledge and those } \\
\text { skills to demonstrate } \\
\text { comprehension and performance in } \\
\text { novel situations. }\end{array}$ & $\begin{array}{l}\text { BGE } \\
\text { Post } \\
\text { experience } \\
\text { Reflection }\end{array}$ \\
\cline { 2 - 5 } & Reflection & 3 & $\begin{array}{l}\text { Reviews prior learning (past } \\
\text { experiences inside and outside of } \\
\text { the classroom) in depth, revealing } \\
\text { fully clarified meanings or indicating } \\
\text { broader perspectives about } \\
\text { educational or life events. }\end{array}$ & $\begin{array}{l}\text { Post } \\
\text { experience } \\
\text { Reflection }\end{array}$ \\
\hline
\end{tabular}

Integration: BGE brings together the Liberal Arts and Business perspectives on national cultural, cultural diversity and the influence of culture on human interaction, whether in business or society. The Cultural Workshop sets the conceptual and personal frameworks for understanding culture and its conditioning on individuals and societal structures. Students set their intentions for cultural learning based on self-assessments. These intentions are enacted and reflected on during the Global Experience. Their understanding of the experience, personal development, and resetting of intentions occurs through reflections during and after the Global Experience.

Innovation: An integrated curriculum allows for cross-disciplinary learning objectives such as cultural competencies to be developed throughout appropriate courses, regardless of whether they are in Global Studies, Modern Languages, Management, or other disciplines. This is in keeping with the longitudinal multifaceted process required for development of global competencies. The Global Experience offers a structure within which all students can engage in an immersive, facilitated global experience. The structure ensures that regardless of which global experience students choose they acquire a broad understanding of culture and cultural influence, engage in self-learning and development, and follow best practices of transformational learning. The overall measure of success for this initiative will be improvement in student learning outcomes, specifically their scores on intercultural effectiveness. In addition, qualitative analysis of student reflections on their own learning will be available from the End of Program Reflection module. Other measures of success include growth in the number of students and faculty participating, as well as increased diversity in the demographics of participants. A profound, yet less easily measured, indicator of success comes from the conversations among students, faculty, and administrators. As the culture of the institution embraces the pervasive need for global education, supply and demand for those opportunities will continue to grow.

\section{Implementation Plan}

The implementation of the Global Experience would follow this schedule:

\begin{tabular}{|l|l|}
\hline \multicolumn{2}{|c|}{ Spring } \\
\hline $\begin{array}{l}\text { Culture in Business \& Society } \\
\text { Workshop }\end{array}$ & $\begin{array}{l}\text { One offering of two-half Saturday sessions for } \\
\text { students in Global Experiences travel courses and } \\
\text { Summer/Fall Study Abroad }\end{array}$ \\
\hline $\begin{array}{l}\text { Cultural Context Workshop for } \\
\text { Faculty }\end{array}$ & One offering of one-day session \\
\hline \multicolumn{2}{|c|}{ Summer } \\
\hline Global Experience & $\begin{array}{l}\text { MG3900 FLP South Africa, short-term faculty led } \\
\text { program }\end{array}$ \\
\hline
\end{tabular}




\begin{tabular}{|l|l|}
\hline Global Experience & $\begin{array}{l}\text { MLSP 205 Intermediate Spanish Language Immersion, } \\
\text { domestic language course }\end{array}$ \\
\hline \multicolumn{2}{|c|}{ Fall } \\
\hline Study Abroad Students & Coaching students enrolled in Study Abroad \\
\hline All Students in above GE's & Post-trip Reflection \\
\hline End of Program Reflection & $\begin{array}{l}\text { On-line program including reflections, self- } \\
\text { assessment, and evaluations }\end{array}$ \\
\hline
\end{tabular}

\section{Effect of the Pandemic}

Just as these questions were being addressed, the world was hit with the coronavirus pandemic (COVID-19) redirecting all efforts towards social distancing, health and safety concerns, and virtual classrooms. With all travel being grounded, and students brought home when and if possible, the urgency for improving global education was stalled. In addition, the options for Global Experiences now had to include virtual global experiences.

When it became clear that travel for educational purposes would be grounded for longer than a few months, options for partnering with institutions around the world to facilitate virtual cultural experiences were considered. Creating the sensory effect of a Global Experience on a zoom meeting requires a rethinking of our course structure and delivery. In one example, Professor Berdrow's travel course to South Africa during which students would have worked with social entrepreneurs in-country, was converted to a oneweek intensive. South African partners joined Bentley students for a few hours each day via zoom to discuss their company challenges, talk with students about viable solutions, and then discuss and evaluate student team presentations. During these shared meetings Bentley students experienced language differences, technology challenges, time differences, and the differing access to information. In addition, South African leaders of social movements and organizations presented their efforts, responding to student questions. During these meetings students saw the physical environments in which the South Africans lived and worked. While not the same as walking down a dirt road in the informal township of Diepsloot, it was more sensory than reading a case or watching a video.

In collaboration with an international education partner, Bentley was able to offer virtual Global Interdisciplinary Internships. Typically, the internships included travel to work in-country with social entrepreneurs while also taking classes on culture, social responsibility, community stakeholders and teamwork. In the virtual version, in-country organizers facilitate synchronous meetings with local entrepreneurs, partner facilitators deliver curriculum sessions, while a faculty advisor at Bentley manages the administrative aspects of the course.

To facilitate the virtual environment academia functions within the student Culture in Business \& Society Workshop was recorded. During the 45 minute video session students were encouraged to pause at certain points to make journal entries. They are still required to complete the intercultural effectiveness self-assessment and complete a selfdevelopment plan based on results. Two videos were recorded for faculty, introducing concepts of Culture General and Culture Specific.

Under COVID-19 regulations of social distancing, service-learning programs in general were halted. The added travel restrictions made international service-learning options impossible to complete. Students might be reluctant to participate if the projects 
were purely online research type projects, lacking any interactions with community partners. Most community partners had needs that required physical presence and interaction, hence they were reluctant to provide access for the sake of efforts like improving operations. Under certain circumstances where relationships existed and need fit the virtual model, partners such as those in South Africa were grateful for the interaction and support. There was always great concern about their involvement when things like internet access comes at a cost. It is a very different situation when students arrive to community partners by their own transportation then when partners are expected to get to an internet café or entrepreneurs' incubator at a particular time.

In the hoped-for post-pandemic world, several components will continue to be offered synchronously via technology. There has always been debate in international education about serving students who for various reasons could not travel (Levintova et al, 2020). These options created when no one could travel will continue in service to those students who are unable to travel yet still wish to engage in global education opportunities.

\section{Discussion}

The Global Experience as a key learning experience in the new curriculum design was never questioned, at least not to the point that it was taken out of the design. Its implementation was not as fully accepted. Questions about responsibility, timing, tracking, and sanctions for non-completion made the implementation a longer than anticipated process. This reluctance to accept significant pedagogical change is reflected in Tagg's (2012) essay on faculty resistance. The team that designs the new curriculum is invested and takes ownership of the data they collect, their interpretation of the data, and the resulting design changes. Those on the approval team have not taken ownership, have not engaged in the process, and are being asked to adopt a curriculum that requires them to change - to take a risk rather than stay the course. The challenge lies in keeping everyone involved while also still moving the process forward.

This need to keep everyone informed while still maintaining a manageable time frame and productive workflow was addressed through a transparent, easily accessible communication repository. The curriculum design team used Microsoft SharePoint to post minutes of every meeting, summaries of decisions made, and updates of the current design thinking. It was arduous to simultaneously engage in a complicated design process while also creating clear documentation for others to follow. The team held numerous information sessions for different stakeholders, presented at committee meetings, and provided compelling yet simple presentations at faculty senate and general faculty meetings.

While implementation of the full GE program requires significant commitment on the part of the administration, faculty and staff, there are components that can be introduced on a smaller scale. There are a number of majors and minors that require a global experience to complete the degree. One component that can be implemented is to standardize those global experiences. For example, regardless of whether the GE includes international travel it must include personal interfaces with culturally diverse groups whether in-person or virtual, synchronous (communication) or asynchronous (media). All students enrolled in a GE must watch the culture general and culture specific videos to gain an understanding of culture as a societal and personal construct. The GE must include pre/post self-assessments as well as an end-of-program reflection module. This standardization can be submitted as a curricular proposal for approval. The faculty 
workshops can be offered on a voluntary basis. The Office of International Education who approves proposals for faculty led short term programs could encourage faculty to complete the workshop before designing their program.

The hope is that our model will endure these challenging times, and we will find ways to adapt to the new realities. The need for global experiences to enhance learning will not diminish, if anything they will increase. Buchan, Ravlin and Ozturk (2020) used the $\mathrm{O}^{*} \mathrm{NET}^{3}$ data from 1980 to 2017 to determine that (1) employment share has been increasing for occupations requiring both high non-routine analytical and global interpersonal skills, and (2) task intensity of global interpersonal skills has increased greatly relative to other groups of skills while routine skills demands show a steep decline. Granted the labor market demands will change substantially due to COVID-19 but the need to work effectively in and with cultures different than our own will only continue to grow.

\section{References}

Arhar, Joanne M. (1997). The effects of interdisciplinary teaming on students and teachers. In Judith L. Irvin (Ed.), What Current Research Says To The Middle Level Practitioner, (pp. 49-56). Columbus, OH: National Middle School Association. ED 427847.

Astin, A. (1985). Achieving Educational Excellence. Jossey-Bass.

Beane, James A. (1997). Curriculum Integration: Designing The Core Of Democratic Education. New York: Teachers College Press.

Berdrow, I. \& Bird, A.W.. (2018) Development and Assessment of Intercultural Effectiveness: A LearnerCentered Approach. Journal of Education, Sage, Thousand Oaks, CA: Vol. 198, Iss 2, pp. 136-145.

Berdrow, I., Hightower, C. and Cartwright, C.. (2020 Under Review) Learner Centered Assessment and Development: Three Levels of Perspectives on Instructional Design and Learner Outcomes.

Berdrow, Iris, Allan Bird, Sam Woolford \& Maria Skaletsky. (2020 Under Review) "Intercultural Effectiveness: Do International Education Experiences Move the Needle?”

Berg, D.M. (2020) Preparing Student for the "Next” Global: The Responsibilities and Tools of International Business Education. Academy of International Business Insights. V.20 (1): pp. 24-27.

Buchan, N.R., Ravlin, E.C., and Ozturk, O.D. (2020) Changes in Globalization: How Should IB Education Respond? Academy of International Business Insights. V.20 (1): pp. 15-19.

Drake, S. M. (1993). Planning integrated curriculum: The call to adventure. Association for Supervision and Curriculum Development, Alexandria, VA.

Gaudelli, W., and Laverty, M.J. (2015) Education and Culture, Purdue University Press, V31 (2), pp. 13-26

Hruby, J., Calixto, C.V., and Mukhi, U. (2020) Conceptualizing the Responsible Learning Framework for International Business Faculty Development. Academy of International Business Insights. V.20 (1): pp. 10-15.Leeman, Y. and Ledoux, G. (2005) Teachers on intercultural education, Teachers and Teaching, 11:6, pp. 575-589, DOI: 10.1080/13450600500293258

Levintova, K., Smith, S., Cruise, R., Berdrow, I., Boudon, L., Paracka, D. \& Worley, P. (2020) Have Interest, Will NOT Travel: Multi-Institutional Study of Unexpected Reasons of Why Students Opt Out of Study Abroad. In Nina Namaste \& Amanda Sturgill (eds), Mind the Gap: Integrating Learning at Home and Abroad. Stylus Publishing, Inc.

Mezirow, J., Taylor, E. W., \& Associates. (2009). Transformative Learning in Practice: Insights from Community, Workplace, and Higher Education. San Francisco, CA: John Wiley \& Sons.

National Association for Core Curriculum. (2000). A Bibliography Of Research On The Effectiveness Of Block-Time, Core, And Interdisciplinary Team Teaching Programs. Kent, $\mathrm{OH}$.

O’Hara, M. \& Leicester, G. (2012) Dancing at the Edge: Competence, Culture and Organization in the $21^{\text {st }}$ Century. Triarchy Press: Devon, UK.

Paige, R. M. (Ed.). (1993). Education for the intercultural experience. Nicholas Brealey Publishing.

\footnotetext{
${ }^{3}$ The O*NET database and employment statistics is provided by the American Community Survey and Census Data.
} 
Schmidt-King, A. (2020) The Renewed Relevancy of High-Impact Practices (HIP): Doubling Down on our HIP Identity in Support of Responsible IB Education. Academy of International Business Insights. V.20 (1): pp. 20-23.

Tagg, J. (2012): Why Does the Faculty Resist Change? Change: The Magazine of Higher Learning, 44:1, 6-15 Vande Berg M. , (2016) Intercultural learning through education abroad: Theories, processes and practices. Webinar: Institute for Cross-Cultural Teaching and Learning 21 January 2016.

Vars, Gordon F. (1996). Effects of interdisciplinary curriculum and instruction. In Peter S. Hlebowitsh \& William G. Wraga (Eds.), Annual Review of Research For School Leaders (pp. 147-164). Reston, VA: National Association of Secondary School Principals and Scholastic Publishing.

Vars, Gordon F. (1997). Effects of integrative curriculum and instruction. In Judith L. Irvin (Ed.), What Current Research Says To The Middle Level Practitioner (pp. 179-186). Columbus, OH: National Middle School Association. ED 427847.

Vars, Gordon F. \& Beane, James A. (2000) Integrative Curriculum in a Standards-Based World. ERIC Clearinghouse on Elementary and Early Childhood Education, ED441618 Champaign IL.

\section{Author Biographies}

Dr. Iris Berdrow is a tenured Professor of Management and Director of the MBA program at Bentley University (Waltham, MA, USA), has taught at Harvard University Summer School (Cambridge, MA, USA), as well as internationally in France, Germany, Austria, Scotland, and Morocco. She holds an MBA and Ph.D. with a concentration in Organizational Behavior and International Management from the Richard Ivey School of Business, University of Western Ontario, London, Canada. Her research interests are in intercultural effectiveness, globally oriented pedagogy, effective assessment, employee competencies and competency based education. Iris is published in MIT Sloan Management Review, Strategic Management Journal, Long Range Planning, and the Journal of World Business, among others. She is coauthor of Bases of Competence: Skills for Lifelong Learning and Employability (Evers, Rush \& Berdrow, 1998).

Dr. Samir Dayal is Professor of English and Media Studies at Bentley University. He holds a Ph.D. from the University of Wisconsin-Madison. His research interests are in Film Studies; Globalization; South Asian Studies; Psychoanalysis; Cultural Studies; Postcolonial Literature, Film \& Culture. He is a member of the Board for Society for the Psychological Study of the Arts (PSYART); Editorial Board Member, PSYART Journal; Member, Development Committee, Advanced Placement Exam: English Literature Advisory Board, 2010-2015; Assistant Chief Reader, Advanced Placement Exam Reading for English Literature; and member of The Society for Multi-Ethnic Studies: Europe and the Americas.

Shawn Hauserman is an Adjunct Lecturer of Management and Associate Director of the Center for Service-Learning and Engaged Learning at Bentley University. Shawn holds an MBA from Bentley University, and a Master's from Gonzaga University . His research interests are in Human Trafficking and Global Slavery Ethical Supply Chain Management Comic Books and Graphic Novels as Educational Resources.

Natalie Schlegel is Director of International Education at Bentley University in Waltham, Massachusetts. She oversees international partnerships and a diverse portfolio of education abroad programs that serve approximately 700 students annually, positioning Bentley as a leading institution for undergraduate participation and mid-length duration in study abroad, according to the Institute for International Education's OpenDoors report. Natalie earned a BA in Economics and Spanish from Vanderbilt University, and an 
MBA from Bentley University. She is a member of NAFSA's Trainer Corps and the Workshop Dean for the Managing the Education Abroad Office workshop.

Lauren Schuller is Associate Director of International Education at Bentley University. She holds an MA in Higher Education Administration from Boston College and a BA in Spanish from UMass - Amherst. 